\title{
Biogas production from cow dungs using a modified fixed-dome digester
}

\author{
Mtamabari Simeon Torbira and Ebigenibo Genuine Saturday * \\ Department of Mechanical Engineering, University of Port Harcourt.
}

Global Journal of Engineering and Technology Advances, 2021, 07(03), 224-230

Publication history: Received on 28 March 2021; revised on 15 June 2021; accepted on 18 June 2021

Article DOI: https://doi.org/10.30574/gjeta.2021.7.3.0066

\begin{abstract}
A modified fixed dome digester with stirring mechanism has been designed and constructed and used for the anaerobic digestion of cow dung slurry at 5\%-7\% Total solid (TS) concentration within the mesophylic temperature range. The quality of biogas gas produced was between $54 \%-69 \%$ methane $\left(\mathrm{CH}_{4}\right)$ content. The Carbon to Nitrogen ratio (C: $\mathrm{N}$ ) varied between 35:1 - 45:1. Total biogas yield obtained over the detention period was about $261 \mathrm{~L}$. The maximum and minimum temperatures recorded over the 95 days period was $32^{\circ} \mathrm{C}$ and $25^{\circ} \mathrm{C}$ respectively. The volume of biogas yield, $\mathrm{V}_{\mathrm{b}}\left(\mathrm{m}^{3}\right)$ was observed to increase with the percentage total solid, PTS (\%). The details of the design and construction of the biogas digester plant and its cost are reported. The performance of the plant was very satisfactory. Investigation into the anaerobic digestion revealed that cow dung has great potentials for generation of biogas.
\end{abstract}

Keywords: Fixed dome digester; anaerobic digestion; Cow dung; Total solid; mesophylic temperature range

\section{Introduction}

The idea of rural settlers, agrarian communities and livestock producers being independent of outside suppliers of their energy requirements is attractive and economical. The present need to direct to sources of new energy and the invention of new conversion technologies can facilitate the reduction of the enormous bio-waste generated in these settings [1]. The full appreciation of biogas generation from bio-waste will not materialize without understanding the meaning of waste and bio-waste. Waste is an unwanted material in the wrong place. Bio-waste is unwanted biodegradable material e.g. cow dung, in the wrong place or environment. The economists define waste as that which is cheaper to throw away than to make further use of [2]. The anaerobic digestion of animal dung or vegetable produces biogas [3]. The anaerobic digestion process or fermentation offers advantages which include a significant reduction in odour emission and pathogens spreading to the environment while producing methane-rich gas (biogas or marsh gas) as an alternative source of energy and stable slurry as a fertilizer and soil manure respectively [4]. In the 1970s, a conference on biogas was convened at the imperial College, University of London. The participants agreed on big potential for biogas technology in many parts of the globe, particularly in the developing world [2]. India, China and Nepal are the leading giants in biogas technology and programme. China launched 7,000,000 dollars on farm family size biogas plant in the early 1980s [2]. India launched the Khadi and Village Industries Commission (KIVC) programme in the 1960s, with developing a quality but expensive biogas plants. Nepal programme started in the same 1960s and there was fastest growth in the 1980s. Biogas has become popular in Brazil, Sweden and many European countries. For instance, an estimated $1.4 \mathrm{TWh}$ of biogas is produced annually in Sweden at approximately 230 facilities. The 135 wastewater treatment plants that produce biogas contribute around half of the production [5]. Biogas production, if carried out at commercial scale, would not only provide an alternative source of energy but would also be a means of waste disposal for Nigeria [6]. Also, a research conducted by Khan et. al [7] revealed further that cow dung and poultry waste as animal waste has great potentials for generation of biogas. Ozor et. al [8] also forecasted in their work that by converting cow dungs into methane biogas via anaerobic digestion, the millions of cows in Nigeria, United States, etc, would be able to

\footnotetext{
${ }^{*}$ Corresponding author: Ebigenibo Genuine Saturday

Department of Mechanical Engineering, University of Port Harcourt.
} 
generate one hundred billion kilowatt of electricity, enough to power millions of homes across the United States. Ukpai and Nnabuchi [9] conducted a research on cow dung, cow pea and cassava peeling using 45 litres biogas digester. The study revealed that cow dung as animal waste has great potentials for generation of biogas and its use should be encouraged due to its early retention time and high volume of biogas yields. In Nigeria and other parts of Africa, biogas programmes have been set up but the technology has not spread or become popular and only few units have been built. Considering the limited amount or quantity of fossil fuel left, and the accompanying environmental pollutions associated with it, biogas generation from bio-waste, as a way of diversifying our energy need or requirements is one safe, cheap and economic and environmentally friendly alternative to meeting our energy demands.

\section{Decomposition Mechanism of Biogas Production}

Organic materials undergo anaerobic digestion to produce biogas. The process is biochemically a very complicated one that involves hundreds of possible intermediate compounds and reactions, and each of these is catalyzed by specific catalysts or enzymes [10]. Despite the complex nature of the reactions, the overall chemical reaction is often simplified to:

Organic Matter: $\frac{\text { anaerobic }}{\text { digestion }}=\mathrm{CH}_{4}+\mathrm{CO}_{2}+\mathrm{H}_{2}+\mathrm{NH}_{3}+\mathrm{H}_{2} \mathrm{~S}$

The breakdown of complex organic materials to release biogas depends on group of bacterial and in general, anaerobic digestion is considered to occur in three stages or phases:

- The hydrolysis phase - liquefaction or polymer breakdown

- Acid formation or acidification

- Methane formation or methanogenesis

All the three phases occur simultaneously in a biogas plant and production of methane gas is affected seriously if only one dominates.

Phase 1: The hydrolysis reactions convert protein, carbohydrate, and fat into amino acids, simple sugars, and long chain fatty acids respectively.

Phase 2: Acid forming or producing bacteria covert the simplified compounds into acetic acid $\left\{\mathrm{CH}_{3} \mathrm{COOH}\right)$, hydrogen $\left(\mathrm{H}_{2}\right)$ and carbon (iv) oxide $\left(\mathrm{CO}_{2}\right)$. The facultative anaerobic bacteria utilize oxygen and carbon in the process of acidification. This creates the anaerobic condition necessary for methanogenesis.

Phase 3: This is the final stage. Here, obligatory anaerobes that are involved in methane formation decompose compounds with low molecular weight to release $\mathrm{CH}_{4}$ and $\mathrm{CO}_{2}$. The reaction is as follows:

$$
\begin{gathered}
\mathrm{CH}_{3} \mathrm{COO}^{-} \text {(acetate) }+\mathrm{H}_{2} \mathrm{O}=\mathrm{CH}_{4}+\mathrm{HCO}_{3}+\text { Energy } \\
4 \mathrm{H}_{2}+\mathrm{HCO}_{3}^{-}+\mathrm{H}^{+}=\mathrm{CH}_{4}+2 \mathrm{H}_{2} \mathrm{O}+\text { Energy }
\end{gathered}
$$

A case of methane production using cellulose molecules as source of materials is exemplified below;

\subsection{Hydrolysis Phase}

$$
\text { Cellulose }\left(\mathrm{C}_{6} \mathrm{H}_{10} \mathrm{O}_{5}\right) \mathrm{n}+\mathrm{H}_{2} \mathrm{O}=\mathrm{n}\left(\mathrm{C}_{6} \mathrm{H}_{12} \mathrm{O}_{6}\right) \text { glucose }
$$

\subsection{Acid Phase}

$$
\left(\mathrm{C}_{6} \mathrm{H}_{12} \mathrm{O}_{6}\right)+\mathrm{HO}-2 \mathrm{CH}_{3} \mathrm{CHOHCOOH}
$$

\subsection{Methane Phase}

The methane phase is characterized by the following reactions: 


$$
\begin{aligned}
& 2 \mathrm{CH}_{3} \mathrm{CH}_{2} \mathrm{COOH}+2 \mathrm{H}_{2} \mathrm{O}+\mathrm{CO}_{2}-4 \mathrm{CH}_{3} \mathrm{COOH}+\mathrm{CH}_{4} \\
& \mathrm{CH}_{3} \mathrm{COOH}-\mathrm{CO}_{2}+\mathrm{CH}_{4} \\
& 4 \mathrm{H}_{2}+\mathrm{CO}_{2}-2 \mathrm{H}_{2} \mathrm{O}+\mathrm{CH}_{4} \\
& 2 \mathrm{CH}_{3} \mathrm{CH}_{2} \mathrm{OH}+\mathrm{CO}_{2}-2 \mathrm{CH}_{3} \mathrm{COOH}+\mathrm{CH}_{4}
\end{aligned}
$$

The resulting biogas sometimes referred to as "Gober" gas or "Marsh" gas consist of methane $\left(\mathrm{CH}_{4}\right) 70 \%$ and carbon (iv) oxide $\left(\mathrm{CO}_{2}\right) 25 \%$ and some trace of other gases, e.g $\mathrm{H}_{2} \mathrm{~S} 1 \%, \mathrm{~N}_{2} 3 \%, \mathrm{H}_{2} 1 \%$.

There is environmental requirement for anaerobic digestion in a digester. Some of these parameters include temperature (optimum $37^{\circ} \mathrm{C}$, Mesophilic), and (50-60드. thermophilic), PH value (7.0 -7.2), C/N ratio (25-40), hydraulic retention time [HRT] (days), loading rate, alkalinity etc. Anaerobic digestion is a multi-parameter-controlled process, each parameter having control over the process either through its own effect on the system or through interaction with the other parameters. The biodegradability of the organic substrate is one of the most important parameters affecting the performance of digesters. Usually biodegradable material constitutes 30 to $50 \%$ of the total waste [11].

\section{Material and methods}

A modified fixed-dome digester was designed, constructed and used for the anaerobic digestion of cow dung in this work. A biogas plant consists of the digester and the gas storage space. A biogas digester is used for converting fermentable or digestible organic matter into combustible gas, methane and fully matured organic matter (slurry).

There are different designs of biogas digesters and they may be classified as follows:

- The continuous plant with automatic discharge at the overflow and feeding is frequent.

- The batch plant in which the feeding is at intervals.

There are three main types of biogas plants suitable for rural and agrarian dwellers, the fixed-dome plant, the floating drum plant and the plastic covered ditch. The fixed-dome type is usually referred to as the Chinese type and is preferred to floating gas holder (drum). The floating drum digester is more expensive and is susceptive to corrosion damage as the drum is made of steel but requires relatively less excavation. In farms located in cold regions (below $25^{\circ} \mathrm{C}$ ), passive or active heating of biogas digesters in the farm may be required to achieve the desired optimum temperature i.e. $37^{\circ} \mathrm{C}$, best for greater fermentation while at same time keeping the hydraulic retention time short. The modified fixed dome biogas digester constructed in this work is different from the Chinese fixed dome design because it is made of mild steel plate, welded together, whereas the Chinese type is made of burn bricks and cement blocks. Geometrics relations were used in calculating the various parameters in the fixed dome as in [2].

$$
\begin{aligned}
& \mathrm{D}=\mathrm{Vol}^{\frac{1}{3}} *(1.173) \\
& \mathrm{P}_{1}=\mathrm{R}^{2}+\frac{\mathrm{F}_{1}^{2}}{2 \mathrm{~F}_{1}} \\
& \mathrm{~V}_{1}=\frac{\left(3 \mathrm{R}^{2}+\mathrm{F}_{1}^{2}\right) \pi \mathrm{F}_{1}}{6} \\
& \mathrm{~V}_{2}=\pi \mathrm{R}^{2} \mathrm{H} \\
& \mathrm{S}_{1}=2 \pi \mathrm{P}_{1} \mathrm{~F}_{1} \\
& \mathrm{~S}_{2}=\pi \mathrm{DH} \\
& \mathrm{Vol}_{0}=\pi \mathrm{r}^{2} \mathrm{~h}_{0} ; \mathrm{S}_{01}=\pi \mathrm{dh} ; \mathrm{S}_{02}=\pi \mathrm{r}^{2}
\end{aligned}
$$

Where; $\mathrm{D}=$ Diameter of the digester cylinder body, $\mathrm{D}=2 \mathrm{R}$.

$\mathrm{H} \quad=\quad$ Height of the digester cylinder body 


$$
\begin{array}{lll}
\mathrm{P}_{1} & = & \text { Radius of digester top dome } \\
\mathrm{F}_{1} & = & \text { Height of top dome. } \\
\mathrm{Vol}_{\mathrm{d}_{\mathrm{d}}} & = & \text { Volume of digester: } \mathrm{V}_{1}+\mathrm{V}_{2} \\
\mathrm{~S}_{\mathrm{d}} & = & \text { Surface area of digester }=\mathrm{S}_{1}+\mathrm{S}_{2} \\
\mathrm{D}_{0} & = & \text { Surface area of outlet chamber. } \\
\mathrm{H} & = & \text { Height of outlet chamber. } \\
\mathrm{Vol}_{0} & = & \text { Volume of outlet chamber. } \\
\mathrm{S}_{\mathrm{O}} & = & \text { Surface area of outlet chamber: } \mathrm{S}_{01}+\mathrm{S}_{02}
\end{array}
$$

The required materials for the fabrication of the fixed dome biogas plant were properly inspected and carefully selected. Two rectangular sheets of mild steel gauge 16 and pipes were cut to the desired dimension of parts of the plant with the aid of marking tools e.g. tape, scriber and cutting machine. Before folding the sheets, the side of the sheets which will form the inner surface was properly coated with oil paint for 2 to 3 coatings. This is because the inside surface will be in constant contact with slurry, which is a chemical agent for that promotes corrosion. Next was the folding of these sheets into cylindrical shape with the use of folding machine. Following folding was the joining of the ends by welding operations. Welding was done using 2 packets of gauge 12 electrode fittings and pipes were then welded to the main cylinder body. Also welded to the body was the top dome. To prevent corrosion, the fabricated digester was coated with oil paint of ox-blood red coloration. This coating also ensures aesthetics of the plant too. Figure 1 shows the structure of the fixed dome digester.

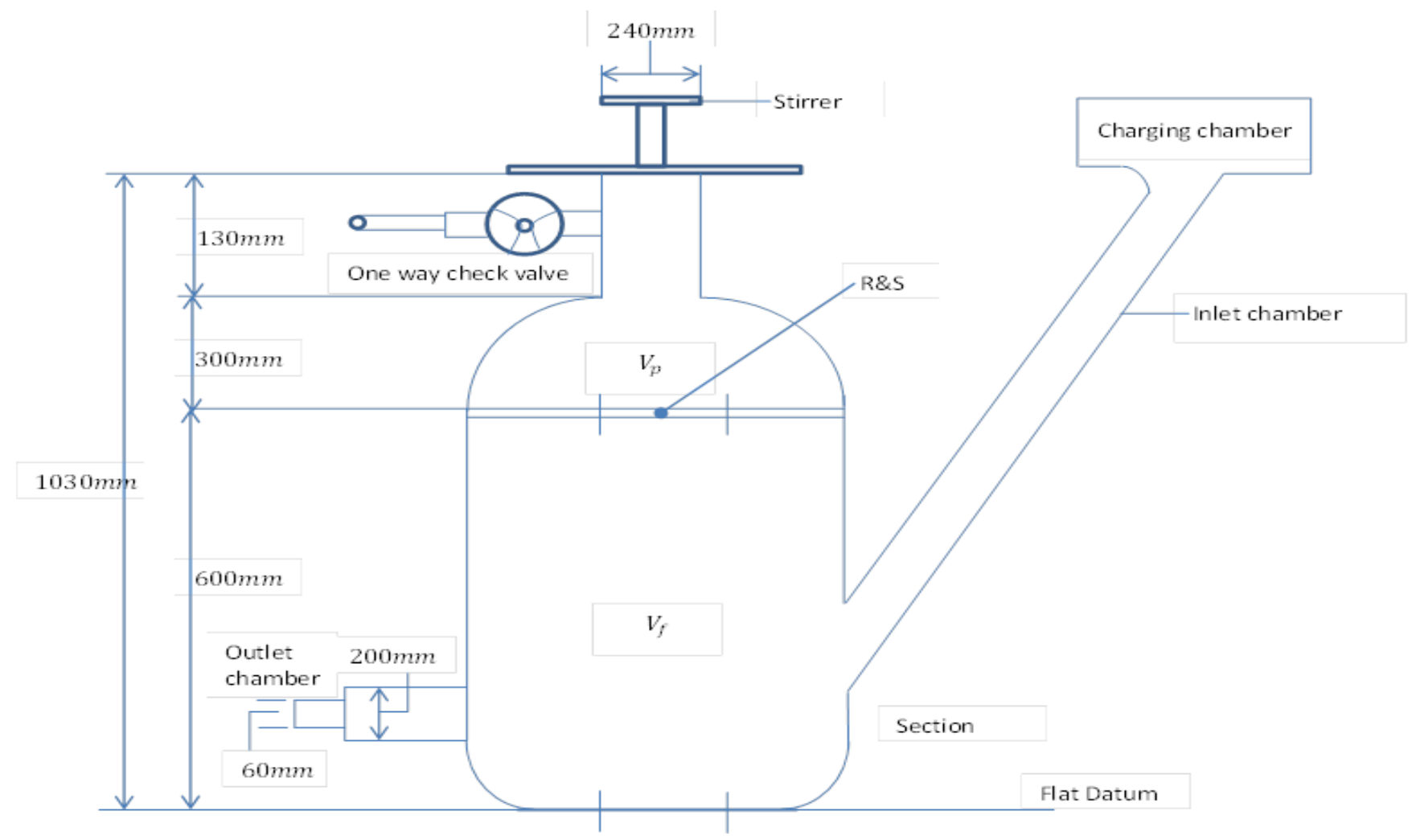

Figure 1 Structure of modified fixed dome digester

Table 1 shows details of the manufacturing of the fixed-dome biogas digester while Table 2 shows the cost analysis and the bill of quantity of the plant. 
Table 1 Material quantity and manufacturing method

\begin{tabular}{|c|l|c|l|}
\hline S/N & Description of part & Quality & Source \\
\hline 1 & Digester & 1 & Fabricated \\
\hline 2 & Pipe & 1 & Purchased \\
\hline 3 & Hose & 1 & Purchased \\
\hline 4 & One direction value & 1 & Purchased \\
\hline 5 & Burner & 1 & Fabricated \\
\hline 6 & Purifying chamber & 1 & Fabricated \\
\hline
\end{tabular}

Table 2 Cost analysis and bill of quantity

\begin{tabular}{|c|l|c|c|c|}
\hline S/N & \multicolumn{1}{|c|}{ Description of materials } & Quality & Rate (Naira) & Amount (Naira) \\
\hline 1 & Mild steel sheet 1.5mm & 2 & 30,000 & $60,000.00$ \\
\hline 2 & Packet of cast iron electrode 12 gauge & 1 & 4000 & 4,000 \\
\hline 3 & Director flow valve & 1 & 6,000 & 6,000 \\
\hline 4 & Filling of pipe & 1 & 70,000 & 70,000 \\
\hline 5 & Bolts and nuts & 20 pieces & 300 & 6,000 \\
\hline 6 & Tin of paint & 2 & 4,500 & 9,000 \\
\hline 7 & Tin of filler & 1 & 3,000 & 3,000 \\
\hline 8 & Cow dung in bags & 3 & 1,500 & 4,500 \\
\hline 9 & Transportation & 3 & 5,000 & 15,000 \\
\hline 10 & Filling stone & 1 & 6,000 & 6,000 \\
\hline 11 & Cutting stone & 1 & 4,000 & 4,000 \\
\hline 12 & Water hyacinth & 2 & 3,000 & 3,000 \\
\hline 13 & Three mins gum tm tube & 1,500 & 3,000 \\
\hline & Total & & $193,500.00$ \\
\hline
\end{tabular}

\section{Results and discussion}

The biogas plant was feed continuously for 3 days using dried pulverized cow dung mixed with 20 liters of water in ratio of 50:50. Sliced water hyacinth was added to boost biogas yield. Stirring was done at least 5 times daily for 12 days. The biogas produced from the plant burnt with a paled yellow colour indicating the presence of impurities such as $\mathrm{H}_{2} \mathrm{~S}$, $\mathrm{CO}_{2}, \mathrm{~N}_{2}$ etc. The biogas was further passed through caustic soda tank to remove gas impurities and then it was observed to burn with brighter blue flame. The performance of the biogas digester plant was very satisfactory. Table 3 shows the results of the measured parameters for the biogas generation from anaerobic digestion of cow droppings at 7\% TS concentration within the mesophilic (35-40) temperature range. The daily biogas yield and percentage of methane $\left(\% \mathrm{CH}_{4}\right)$ gas agrees with the work of Merkel [4]. 
Table 3 Mean weekly biogas yield from plant

\begin{tabular}{|c|c|c|c|}
\hline Week & Temperature $\left({ }^{\circ} \mathrm{C}\right)$ & $\begin{array}{c}\text { Gas yield } \\
\text { (litre) }\end{array}$ & $\% \mathrm{CH} 4$ \\
\hline 2 & 35 & 17.5 & 55 \\
\hline 3 & 33 & 18.17 & 56 \\
\hline 4 & 36 & 39.5 & 45 \\
\hline 5 & 37 & 35.5 & 54 \\
\hline 6 & 34.5 & 27 & 56 \\
\hline 7 & 36.5 & 20 & 54 \\
\hline 8 & 37.5 & 15.5 & 54 \\
\hline 9 & 32.5 & 14.5 & 54 \\
\hline 10 & 36 & 10.5 & 55 \\
\hline 11 & 37 & 10.5 & 56 \\
\hline 12 & 34 & 18.2 & 69 \\
\hline 13 & 33 & 20.5 & 55 \\
\hline 14 & 32 & 12.4 & 69 \\
\hline \multicolumn{2}{|c|}{ Total yield } & 261 & \\
\hline
\end{tabular}

The cow dung was pulverized to increase surface area for microbial attack, hence increases its biodegradability and gas yield. The result obtained showed that the detention time-lasted for 96 days. The daily biogas yield varied from 1.3 to 4.5 liters while the percentage of methane $\left(\mathrm{CH}_{4}\right)$ in the biogas varied between $54 \%-69 \%$. The daily yield showed an impressive production throughout the retention period yielding a total of about 261 liters, which was recorded at the end of detention period. The highest daily yield was recorded on the $27^{\text {th }}$ and $28^{\text {th }}$ days while the least yield of 1.31 litres was observed on the 79th day of detention. Daily yield did not fall below 1.0 litre throughout. Some key parameters of the gas yield are shown in Table 4.

Table 4 Key parameters of the gas yield

\begin{tabular}{|c|l|c|}
\hline S/N & \multicolumn{1}{|c|}{ Parameter } & Value \\
\hline 1 & Gas yield (L) & 261 \\
\hline 2 & $\% \mathrm{CH}_{4}$ & 60 \\
\hline 3 & Temperature $\left({ }^{\circ} \mathrm{C}\right)$ & 37.5 \\
\hline 4 & Detention time (days) & 96 \\
\hline 5 & C: N ratio & $40: 1$ \\
\hline 6 & PH & 7.2 \\
\hline 7 & Feeding & Continuous \\
\hline
\end{tabular}

Table 5 shows the variation of gas yield $V_{b}$ with percentage total solid (PTS). The gas yield obtained for different PTS values follows the relation given by Igoni, et al. [12]. 
Table 5 Volume of gas yield vs percentage total solid

\begin{tabular}{|l|c|c|c|c|c|c|c|c|c|c|c|}
\hline PTS (\%) & 2 & 3 & 4 & 5 & 6 & 7 & 8 & 9 & 10 & 11 & 12 \\
\hline $\mathrm{V}_{\mathrm{b}}\left(\mathrm{m}^{3}\right)$ & 1.52 & 4.67 & 10.38 & 19.26 & 31.93 & 48.94 & 70.83 & 98.22 & 131.5 & 171.30 & 218.1 \\
\hline
\end{tabular}

\section{Conclusion}

A modified fixed-dome digester was constructed and used for cow dung production in this work. For a detention time of 96 days, the total biogas yield was 261 litres with the resulting gas consisting of $60 \%$ methane. The highest biogas yield was obtained in the $27^{\text {th }}$ and $28^{\text {th }}$ days. The variation of gas yield with percentage total yield follows the relation in established literatures. The modified fixed-dome digester is easy to construct and it can be used for biogas production, especially for agrarian communities.

\section{Compliance with ethical standards}

\section{Acknowledgments}

The authors are grateful to the management of Concordia farms limited, Norwa, Tai, Rivers state for providing various supports. Thanks are also due to the Department of Mechanical, University of Port Harcourt for providing a conducive environment at the report writing stage.

\section{Disclosure of conflict of interest}

This work was not sponsored by any organization, individual or agency and there is no conflict of interest of any form.

\section{References}

[1] Torbira MS. Techno-economic analysis of a model biogas plant for agricultural applications: A case study of the Concordia Jarms Limited, Nonwa, Tai, Rivers State”, M.Eng Thesis, Department of Mechanical Engineering, University Nigeria, Nsukka, Nigeria. 2009.

[2] Dioha IJ, Gulma MA, Nabade K. A modified 10m3 fixed-dome community biogas plant, Nigeria Journals of Solar Energy. 2003; 14: 126-134.

[3] Atanu OS, Asere AA, Philip TK. Biogas generation from anaerobic digestion of animal dung, National Solar Energy Forum (NASF 2009), University of Agriculture, Makurdi, Proceedings, Solar Energy Society of Nigeria SESN. 2009.

[4] Merkel AJ. Managing livestock waste, AVI Publishing Company Inc. 1981; 290 - 299.

[5] Swedish Gas Technology Centre. Basic data on biogas, 2nd edition. 2012. [cited 2021 March 15]. Available from http://www.sgc.se > ckfinder > userfiles > files.

[6] Onwuliri, FC, Onyimba IA, Nwaukwu IA. Generation of biogas from cow dung, J Bioremed Biodeg. 2013; 18 : 1-3.

[7] Al Imam, FI, Khan MZH, Sarkar MAR, Ali SM. Development of biogas processing from cow dung, poultry waste, and water hyacinth, International Journal of Natural and Applied Science. 2013; 2(1): 13-17.

[8] Ozor OC, Agah KI, Nnachi AU, Udu-Ibiam OE, Agwu MM. Biogas production using cow dung from Abakaliki abattoir in South-Eastern Nigeria, International Journal of Scientific \& Technology Research. 2014; 3(10): 237239.

[9] Ukpai PA, Nnabuchi MN. Comparative study of biogas production from cow dung, cow pea and cassava peeling using 45 litres biogas digester, Advances in Applied Science Research. 2012; 3(3): 1864-1869.

[10] Torbira MS. Techno-economic analysis of a model biogas plant for agricultural applications: A case study of the Concordia Farms Limited, Nonwa, Tai, Rivers State", Proceedings of the Second International Seminar on Theoretical Physics \& National Development, 5th - 8th July 2009, Abuja, Nigeria. 2009.

[11] Agunwamba JC. Waste engineering and management Tools, Immaculate Publications Ltd.Enugu, Nigeria. 2001.

[12] Igoni AH, Abowei MFN, Ayotamuno MJ, Eze CL. Effect of total solids concentration of municipal solid waste on the biogas produced in an anaerobic continuous digester, Agricultural Engineering International, The CIGR E-Journal. Manuscript EE 07.010. 2008; 10: 1-11. 